\title{
ИMEHА. ПОРТРЕTЫ
}

\author{
К 120-ЛЕТИЮ
}

УДК 821.161.1-054.7"19"

ББК 83.3(2=411.2)6-008.6

DOI 10.25281/2072-3156-2018-15-3-330-339

\section{М.Е. БАБИЧЕВА}

\section{ЭВОЛЮЦИЯ ТВОРЧЕСТВА В.Б. СВЕНА: ОТ ОЧЕРКОВ И РАССКАЗОВ ДО БОЛЬШОЙ ЭПИЧЕСКОЙ ФОРМЫ}

\section{Майя Евгеньевна Бабичева,}

Российская государственная библиотека, научно-исследовательский отдел библиограсрии, ведущий научный сотрудник

Воздвиженка ул., д. 3/5, Москва, 119019, Россия

кандидат филологических наук

E-mail: BabichevaME@rsl.ru

Реферат. Статья является первой попыткой ввести в отечественный культурный оборот творческое наследие В.Б. Свена, 120-летие со дня рождения которого отмечалось в 2017 году. Этот писатель второй волны русской эмиграции в настоящее время почти неизвестен на родине. Произведения его, однако, вполне заслуживают внимания отечественных читателей и исследователей. Во-первых, творчество В.Б. Свена в силу высокого художественного уровня его произведений является неотъемлемой частью российской культуры. Во-вторых, писатель отразил в литературе целый ряд интересных историко-культурных феноменов, характерных для эпохи, о которой он пишет. Литературоведческий анализ произведений В.Б. Свена дается в соотнесении с его необычной биографией. Многие факты из жизни писателя отражены только в малодоступных источниках, в настоящей работе они впервые представлены широкой аудитории.

Специфика творческого почерка В.Б. Свена рассмотрена в статье в эволюиионном развитии. Разработана периодизация литературного массива, созданного писателем, и обоснована условность его деления по периодам. Показано влияние на творчество В.Б. Свена М.М. Пришвина, определено место писателя в эмигрантской литературе, проанализированы отзывы на его произведения современных автору 
критиков-эмигрантов. Значительное внимание уделяется художественному новаторству В.Б. Свена, его экспериментам в области художественной формы, характерным для поздних произведений. Особо отмечен мистический элемент в мировоззрении $и$, соответственно, в творчестве писателя и тесно связанный с ним специфический культурный феномен «система» Миклашевского, ставшая содержательным и структурным иентром одного из произведений.

В статье проводится различие между сложностью увидеть прижизненные печатные издания В.Б. Свена, с одной стороны, и доступностью собственно текстов его произведений в оцифрованном виде - с другой. Акцентируется значимость в такой ситуации информации о существовании произведений, об их достоинствах и о возможности доступа к ним. В списке источников дан перечень сайтов, где можно ознакомиться с основными сочинениями автора.

Ключевые слова: В.Б. Свен, русская эмиграция, социальный конфликт, революция, эволюция, культура, литература, творческое наследие, жанр, психологизм.

Для цитирования: Бабичева М.Е. Эволюция творчества В.Б. Свена: от очерков и рассказов до большой эпической формы // Обсерватория культуры. 2018. T. 15, № 3. С. 330-339. DOI: 10.25281/2072-3156-2018-15-3-330-339.

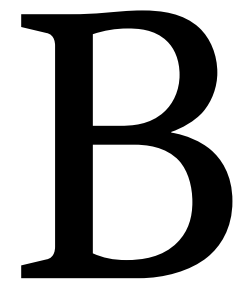

иктор Борисович Свен (настоящая фамилия - Кублицкий, по другой версии - Кульбицкий, 1897-1971) - один из самых старших писателей второй волны русской эмиграции. Его произведения почти неизвестны современным читателям и исследователям на родине. Биографические сведения о нем, включая подлинную фамилию, - немногочисленны и не всегда однозначны. Родился в 1897 г. в селе Охона Новгородской губернии (другая версия - в Охонове). Окончил классическую гимназию (предположительно, в Смоленске). Первые очерки и рассказы публиковал, начиная с 1915 г. в общественно-литературной га- зете «Смоленский вестник». Во время Первой мировой войны добровольцем ушел на фронт. В 1919-1920 гг. воевал в рядах Добровольческой армии, попал в плен, оказался в советском концлагере, откуда был мобилизован в Красную армию. С 1923 г. работал в журналистике, был разъездным корреспондентом и очеркистом; в 1925 г. стал корреспондентом ТАСС. Как журналист В.Б. Свен объездил многие уголки Советского Союза, побывал на самых значимых участках социалистического строительства.

Во время Великой Отечественной войны оказался на оккупированной территории (по одной из версий - после лагеря для военнопленных, куда попал в октябре 1941 г.). Окончание войны застало В.Б. Свена в Германии. Репрессированный в СССР по политической статье он избежал насильственной репатриации. В конце 1940-х гг. активно сотрудничал с журналом «Грани», работал на «Радио “Свобода”» в Мюнхене. В этом городе писатель прожил до конца жизни, там же похоронен.

Творческое наследие В.Б. Свена не велико по объему. Четыре сборника его произведений были опубликованы в Германии издательствами политэмигрантов в конце 1940-х - середине 1960-х гг. и с тех пор ни разу не переиздавались. Около полутора десятков произведений В.Б. Свена, вошедших в эти сборники, ранее печатались на страницах эмигрантской периодики. Пик журнальных публикаций у В.Б. Свена приходится на первую половину 1950-х гг., последняя датирована 1967 годом. В конце жизни писатель обратился к большой эпической форме, экспериментируя с построением сложного сюжета. В 1964-1965 гг. он пишет повесть «Уже пора», в 1967 г. создает полномасштабную повесть «Семен Осипович», до настоящего времени существующую только в журнальном варианте. В 1969 г. увидела свет последняя книга В.Б. Свена - «Моль» (закончена в 1968 г.). О двух его авторских сборниках («Дикое солнце» и «Тоска») в настоящее время доступна только вторичная информация. Эти произведения неоднократно упоминаются в библиографических списках, завершающих книги автора. Однако нет никаких достоверных сведений о наличии где-либо самих этих произведений. 


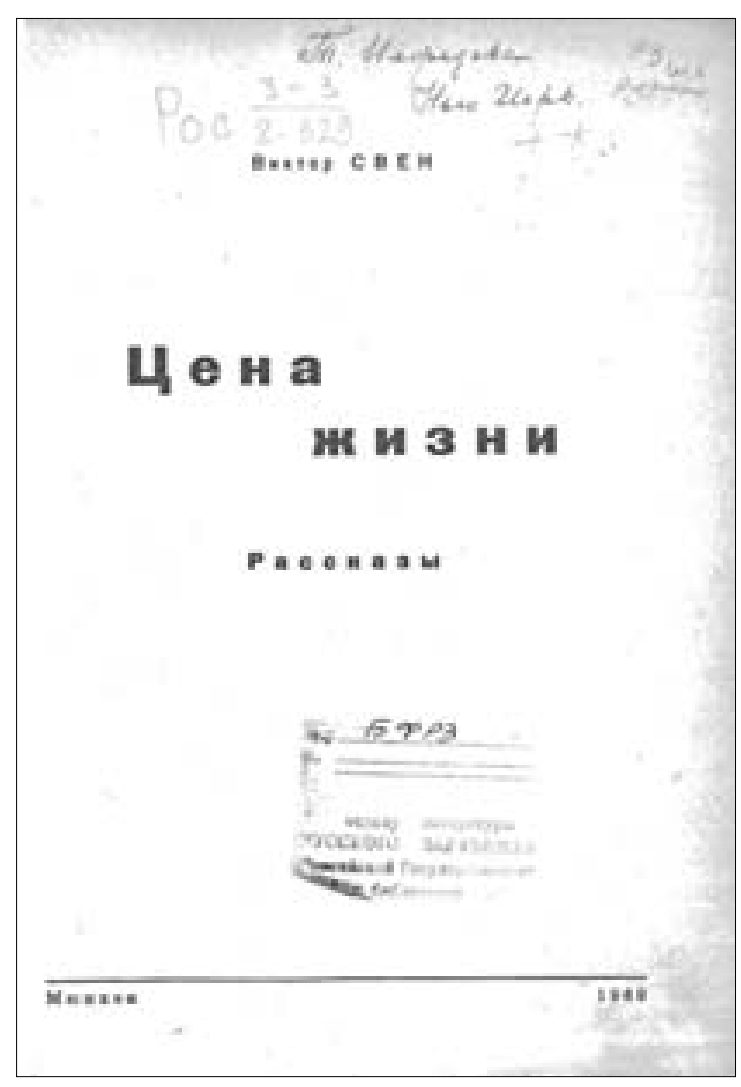

Титульный лист сборника рассказов «Цена жизни» [3]

Критика мало обращалась к творчеству В.Б. Свена, неизменно отмечая влияние на него М.М. Пришвина, с которым этот автор действительно был близко знаком. Он по праву считается продолжателем пришвинской традиции бережного и чуткого отношения к природе, глубокого ее понимания. Этот факт подтверждает и сам писатель в эссе, соответственно озаглавленном «Пришвинское». Слова, сказанные В.Б. Свеном о своем старшем коллеге, в полной мере относятся и к нему самому: «ухо и глаз его по-особенному видят и слышат полет птицы, шорох листвы и журчанье ручья» [1, c. 79]. В то же время, как справедливо указывает современный исследователь В.В. Агеносов, «в отличие от гармоничного Пришвина Свен многие свои наблюдения завершает драматическими финалами: человеческие войны губят ласточек, скворцов» [2, с. 548].

Симптоматичен сам факт, что активно работавший в советской социальной журналистике В.Б. Свен путь в беллетристику начал с рассказов о природе. Пониманию ситуации способствует созданный писателем в рассказе «Распятие» [3, с. 123-137] образ советского скульптора-анималиста. Человек творческий, этот персонаж сознательно выбрал сферой приложения своего таланта изображение животных. Таким образом он смог избежать идеологических рамок, политических акцентов, государственной цензуры и добился максимально возможной в его жизненной ситуации свободы творчества.

К опыту работы в советской, в высшей степени подцензурной журналистике восходит, по-видимому, специфическое сочетание частого обращения к теме природы, которую В.Б. Свен олицетворяет, с одной стороны, и глубокий психологизм в раскрытии характеров персонажей - с другой. Для этого автора характерно стремление сделать героями своих произведений детей, зверей и даже птиц, показать мир, увиденный их глазами, и оценить его через отношение людей к «братьям нашим меньшим». Многие годы работы в журналистике также обусловили тяготение писателя к малым жанровым формам (вплоть до миниатюр) и предельную эмоционально-информационную насыщенность текстов.

Непосредственно в журналистской стилистике В.Б. Свеном написано два цикла очерков (по пяти в каждом): «Канал пяти морей: (Записки журналиста)» [4] и «Селигер: (Очерки обыкновенных дней)» [5]. Эта во многом автобиографическая часть творческого наследия писателя имеет документальную основу. Объективность в изложении фактов сочетается в очерках с вдохновенно-лирическим описанием русской природы, с неподдельным интересом к отечественной истории и гордостью за выдающихся русских людей, как живших в далекие эпохи, так и современников автора.

Красота среднерусской природы, воспетая В.Б. Свеном в «Селигере», становится основной темой в «Охотничьих рассказах» [6]. Мастер литературного пейзажа, автор делает основной акцент на гармонии, свойственной живой природе, и том особом состоянии души, которое соприкосновением с этой гармонией достигается. «Русская природа (многообразная, природа различных областей страны) на свеновских страницах живет и благоухает» 


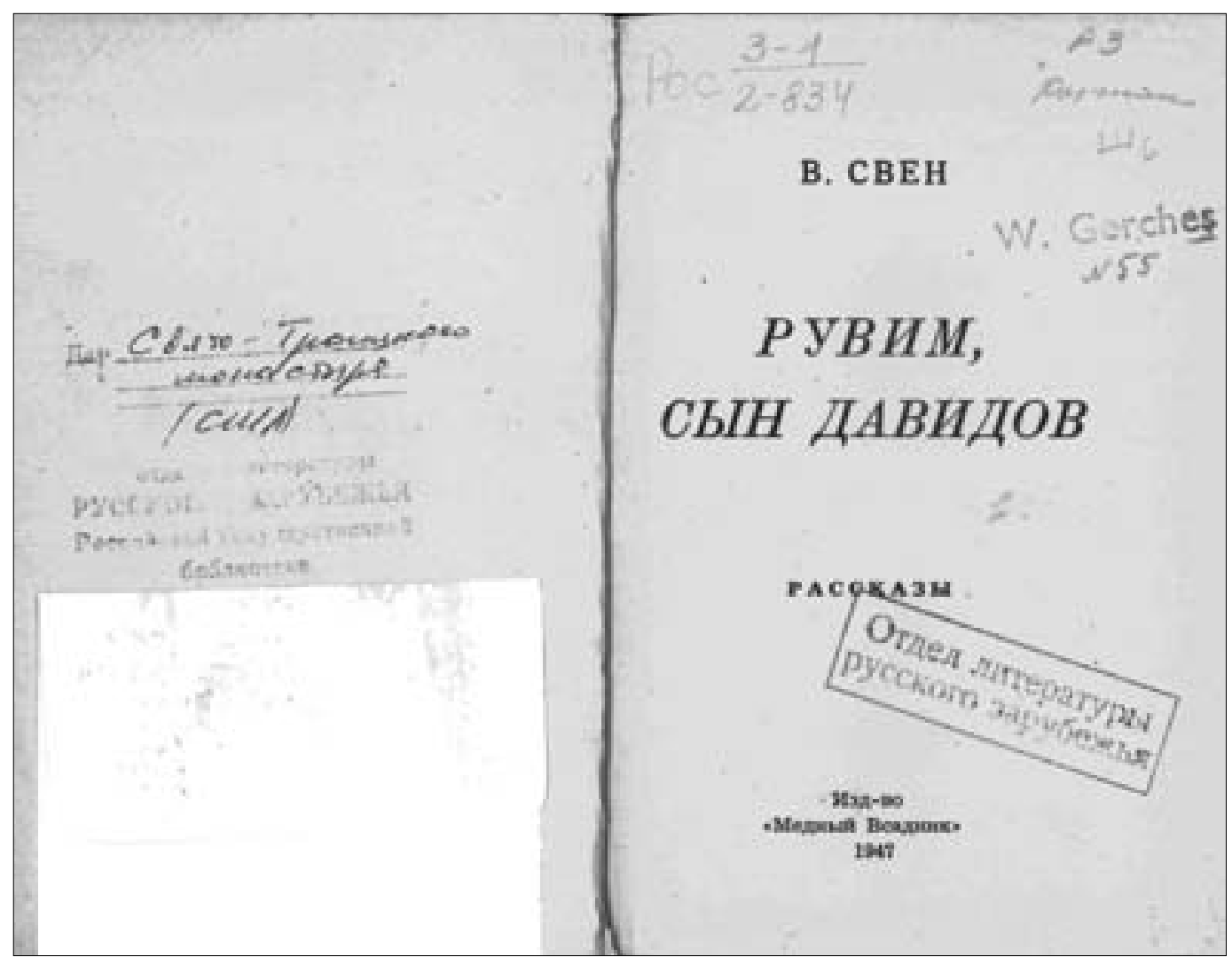

Титульный разворот сборника рассказов «Рувим, сын Давидов» [12]

[7, с. 349], - отмечал современный автору критик Ю.Я. Большухин.

Природа играет значимую роль в психологической прозе писателя. В рассказе «Северная Одиссея» [8, с. 291-310] лес не только место действия, но и один из главных персонажей. Все интересующее автора происходит в душе бойца, который пережил товарища и остался в лесу один. Его посещают то ли видения, то ли просто сны. Лес, наедине с которым он оказался, отражает и определяет его эмоциональное состояние, дает чувство защищенности и пугает, становится свидетелем внутренних мыслей, заставляет усовеститься, вспомнить о Боге.

Звери и птицы, ставшие героями произведений В.Б. Свена - это живые мостики, призванные соединить вечную гармонию природы с миром человека. В свою очередь, среди людей этот автор особенно выделяет тех, кто максимально приближен к природе, как старый бурят Каламбай [9] или северный абориген-охотник Тим [10] из одноименных рассказов. Эти «дети природы» несут в себе мощный нравственный потенциал и при общении благотворно влияют на представителей «цивилизованного» общества. В рассказе «Волк» [11] В.Б. Свен показывает и обратный процесс превращение человека в хищника, противопоставившего себя обществу. Причем на поверку выходит, что именно превратившись в одинокого волка, бывший заключенный смог сохранить в себе истребляемое в современном ему обществе нравственное начало.

Мир животных у В.Б. Свена находится в сложном взаимодействии с миром людей. В повести «Кусочек жизни» [12, с. 35-63] русский эмигрант одиноко зимует в избушке, затерянной в Альпах. Свое alter ego он материализует в мухе, случайно не заснувшей на зиму. В памфлете «Звери» [12, с. 67-87] психологизм тесно переплетен с острой социальной направленностью. В основе сюжета лежит отраженная в заглавии развернутая метафора. Зверями показаны солдаты, долгое время проведшие в блиндаже во время фронтовых действий. И в этой своей сущности они противопоставлены кошке и даже крысам. 


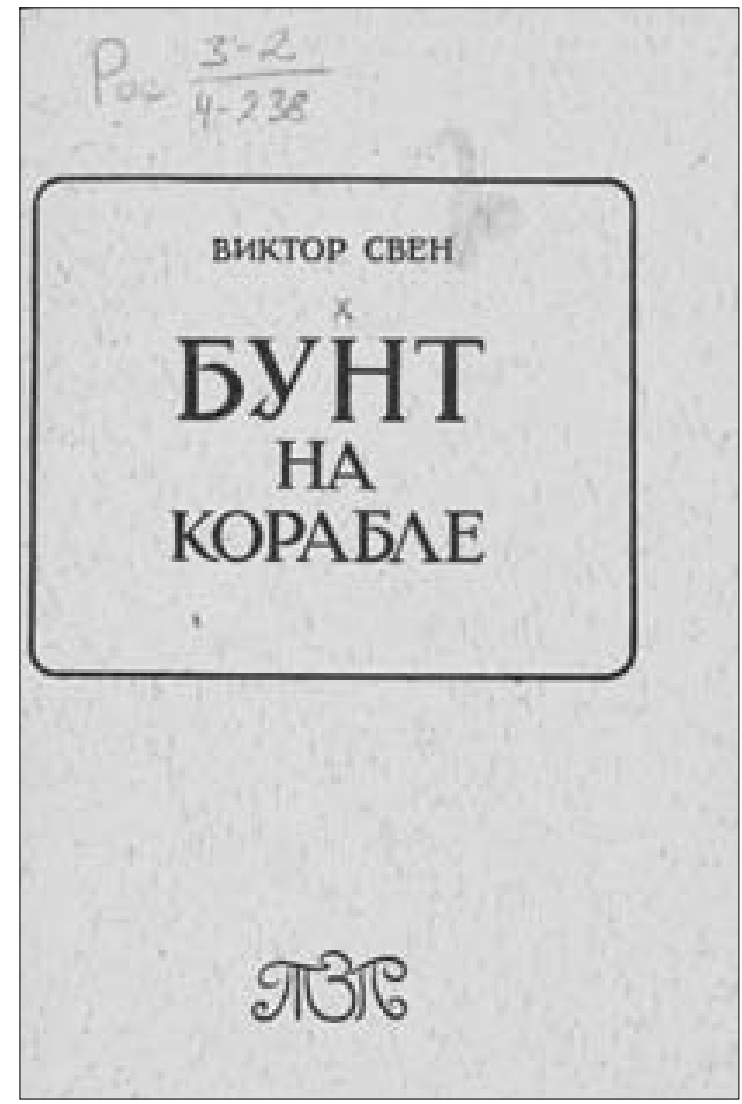

Обложка книги «Бунт на корабле» [13]

Значительная часть произведений В.Б. Свена о природе вошла в сборник «Бунт на корабле» [13]. Название книге дала открывающая ее повесть, впервые опубликованная в 1953 году. $\mathrm{B}$ ней писатель показал окружающее глазами ребенка, а также взаимно обогащающее, плодотворное пересечение взрослого и детского миров. Главные герои - братья Юрка и Томка Желтые - стали позднее центральными персонажами повести В.Б. Свена «Про любовь» [14, с. $168-221]$. Автор использует расширенное понимание слова, вынесенного в заглавие: глубинная привязанность одного существа к другому. Такова, по мнению В.Б. Свена, истинная природа братских отношений. Однако это естественное чувство, показывает автор, не возникает само по себе, должно быть своевременно воспитано у детей старшим поколением. Как и все произведения В.Б. Свена о детях, в эмоциональном плане повесть имеет светлую тональность. Этот фон сохраняется и в тех случаях, когда ребенок сталкивается с жизненной трагедией, даже если драматичной становится его собственная судьба. В рассказе «Ласточки» светлое детское мировосприятие противопоставлено войне как явлению противоестественному. В маленькой повести «Исайка» [3, с. 93-122] герой-подросток, пострадавший, по сути, из-за социального неравенства, стал инвалидом («калечкой»). Таким образом, он как будто навсегда остался не-взрослым, сохранил лучшие детские качества: непосредственность, цельность, открытость и т. д. Светлому мировосприятию этого героя резко противопоставлена агрессивная, разрушительная идеология активистов октябрьского переворота.

С повести «Уже пора» (1964-1965) [14, c. 3-167] начинаются эксперименты писателя в области формы. Современный автору критик Ю.К. Терапиано отмечал: «В повести “Уже пора” Виктор Свен нашел своеобразный подход к теме террора. Повесть состоит из коротких глав, а стиль В. Свена, его скупой, точный и выразительный язык придают ей убедительность и динамичность» $[15$, с. 8] (подробнее о Ю.К. Терапиано см.: [16]).

В повести два центральных действующих персонажа. Оба они безымянны, в сюжете волей судьбы противопоставлены друг другу и в то же время внутренне неразрывно связаны. Один обозначен по занимаемой должности - «следователь по особо важным делам». Второй, государственный преступник, в оперативных сводках проходит под специфическим прозвищем «Уже пора». При всей экзотичности выбрано оно абсолютно точно. «Он пронес, нет, <...> всю свою жизнь прожил под властью этих двух слов» $[14$, с. 18] - характеризует автор человека с таким странным «именем». Для этого персонажа такие слова - сигнал для осуществления долгожданной мести, ставшей смыслом всей его жизни. И в то же время черта, за которой жизнь теряет смысл. Месть «Уже пора» праведна, а потому гораздо эффективнее, чем он планировал и рассчитывал. Следователь, ведущий его дело, постепенно проникается сложным чувством. Чекист осознает, что «у него, у следователя по особо важным делам нет главного, нет внутренней правды, на чем держится “Уже пора” » [14, с. 37]. Большая внутренняя работа, таким образом, приводит следователя к самоубийству, которое в свою очередь придает задним числом высокий смысл гибели «Уже пора». Действие про- 
исходит в 1956 г. после ХХ съезда партии, разоблачившего культ личности. Однако автор не верит в возможность настоящих перемен к лучшему. Единственным реальным путем к свободе в Советском Союзе для своих персонажей он считает уход из жизни.

Активные поиски в области литературной формы В.Б. Свен продолжил повестью «Семен Осипович» [17]. Усложненная форма здесь отражает особенности авторского видения мира в зрелые годы, в частности, склонность к мистике и глубокий психологизм в объяснении реальных событий.

Характерная черта повести - двойное и даже тройное преломление индивидуального восприятия персонажей: особенности психологии действующего лица показываются через его отношение к видению мира другими персонажами. Прежде всего это касается отношения к «системе» (выделено автором. - М. Б.), созданной (открытой?) Миклашевским. Якобы научный способ гарантированно просчитать ход любой азартной игры не только по-разному воспринимается и оценивается людьми, но, в свою очередь, влияет на судьбу каждого. Условен сам факт существования этого отчасти мистического культурного феномена.

Соответственно строится вся система персонажей в повести. Герой-рассказчик вообще не пересекается с Миклашевским, к моменту описываемого действия уже покойным. Как своего рода медиум, живым посредником между ними выступает Семен Осипович, когда-то давно знавший Миклашевского. Повествованию присуща калейдоскопичность эпизодов: воспоминания пожилого человека разнонаправлены по тематике, несоразмерны по объему и нарушают прямую хронологию - прошлое перемежается в сюжете с современными для рассказчика событиями.

Особое место в творческом наследии В.Б. Свена занимает его последняя книга «Моль» [18], написанная сразу после пышного празднования в СССР пятидесятой годовщины Октябрьской революции. Здесь максимально проявились поиски автора в области формы, но главное, четко представлены идеологические установки и политические взгляды, сложившиеся у В.Б. Свена к этому времени. Сложное в жанровом отношении произведение сочетает

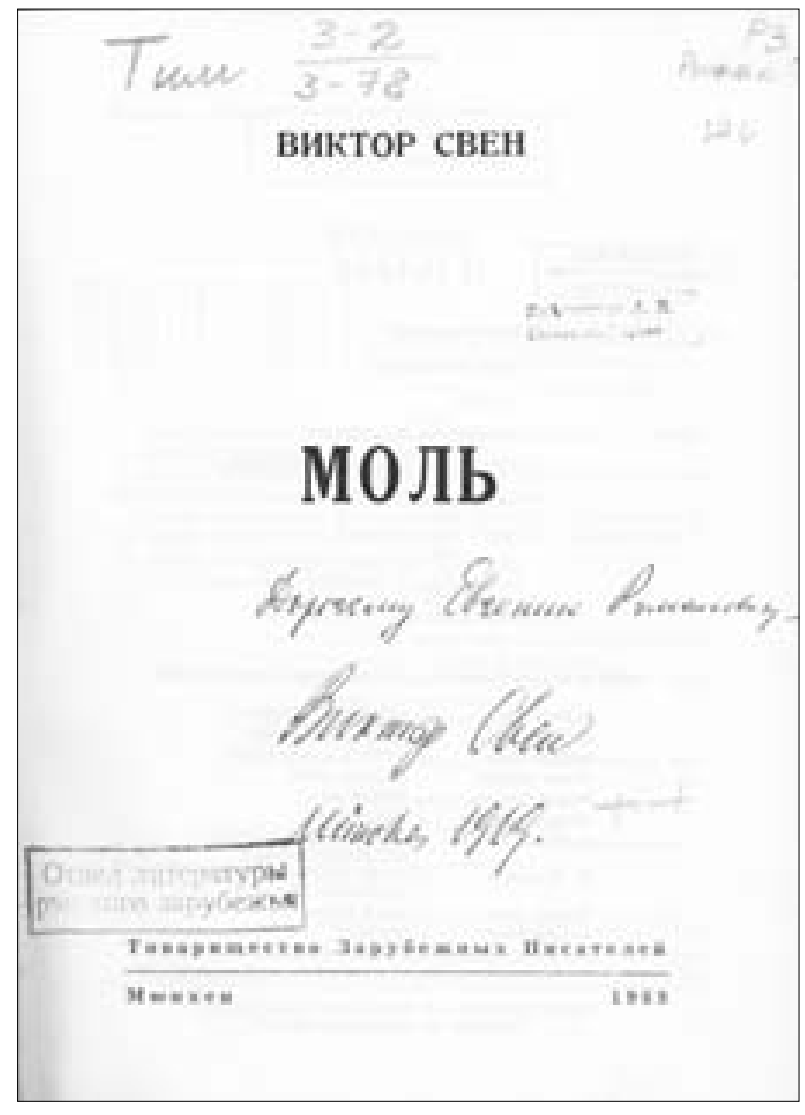

Титульный лист книги «Моль»

с дарственной надписью автора основателю и одному из первых соредакторов журнала «Грани» Е.P. Романову [18]

черты классического реалистического романа, политического памфлета, включает элементы публицистичности и театральности. Наличие последних побудило автора обозначить жанр этого произведения как «действо».

Соответственно, в самое начало повествования вынесен список действующих лиц. Возглавляют его «1. Автор» и «2. Собеседник Автора». За развитием основного сюжета они наблюдают из времени создания произведения, комментируют происходящее и оценивают действия объективизированных персонажей, опираясь на знание дальнейшего хода истории. Основная тема их коллективного осмысления и обсуждения - причины Октябрьской революции и ее последствия для страны. Одно из главных, хотя и спорных утверждений Собеседника, что Советская власть была установлена и смогла удержаться благодаря антирусским (инородным) силам. Неодно- 
кратно в различных вариациях он повторяет эту мысль: «Русского Октября не было и не могло быть, потому что Октябрь делался не русскими руками. <...> Большевиков к власти привели чужие руки» [18, с. 15], «чужими руками был возведен на трон Ленин», «Русского Октября не было, был Октябрь, созданный китайскими, латышскими, венгерскими и прочими чекистами» [18, с. 18].

Другая важная тема разговоров Автора и Собеседника - полный провал попыток создания «нового человека». Жизненным материалом для их обсуждения становится судьба центрального персонажа и множества людей, так или иначе с ним связанных. Чекист Леонид Решков - одновременно типичный продукт и один из главных создателей действительности, в которой существует. Через поступки и мысли этого персонажа В.Б. Свен пытается объяснить сущность Октябрьской революции, по его мнению ставшей огромной трагедией для России. Решков, в свою очередь, склонен к глубокой рефлексии, постоянно анализирует конкретные исторические события, факты, характеры и поведение соратников, а также движения собственной души. Чекист-мыслитель приходит к заключению, что именно он и ему подобные люди несут ответственность за необратимое разрушение нормальной жизни в родной стране. Отмечая жестокость как одну из главных характерных черт сторонников революции, Решков поясняет, что в ее основе лежат страх и зависть: «мы завидуем свободным, умным, непринужденным беседам, интересным - чужим - книгам, завидуем всему улыбающемуся, завидуем чужим красивым женщинам» $[18$, с. 308]. Зависть в данном случае - признание собственной неполноценности, невозможности устранить внутреннее превосходство над собой других людей.

Основной сюжет «Моли» осложнен множеством ответвлений: эпизодов, раскрывающих судьбы жертв революции. Среди них представители бывших привилегированных классов, «раскулаченные» крестьяне, «инакомыслящие» различного социального происхождения, лично неугодные кому-то из чекистов и просто граждане, случайно попавшие под репрессии. Отдельную категорию жертв представляют люди, по внешним признакам относительно благополучные, вписанные в современную действительность и даже занимающие в ней ключевые посты. Таков сам Решков, многие его коллеги-чекисты, их помощники. Партийное руководство и администрация разного ранга. Комсомольцы-добровольцы на строительстве завода в Сибири. Это - нравственно искалеченные, внутренне опустошенные люди. Для них уже невозможно душевное исцеление, их социальное и материальное благополучие неустойчиво и недолговечно, что сами они хорошо понимают.

Анализ литературного наследия В.Б. Свена наглядно показывает эволюцию его творческого почерка, отразившую углубление авторского мировосприятия и стремление к эксперименту в области художественной формы. Произведения раннего этапа творчества писателя имеют самостоятельную ценность, обладают достоинствами, в зрелых сочинениях отсутствующими. В 1958 г. критик Ю.Я. Большухин так характеризовал творчество В.Б. Свена: «Стиль его благородно прост и прозрачен; притом своеобразен, сразу узнаешь его. А между тем, проза Свена не содержит в себе никаких новшеств или словарных ухищрений: традиционная русская речь, в хорошем смысле литературная. Своеобразие идет от творческой индивидуальности писателя» [7, с. 349].

В больших эпических полотнах В.Б. Свена позднего периода затрагиваются серьезные социально-политические проблемы, даны развернутые реалистические картины жизни и типические характеры определенной исторической эпохи. Для этих произведений свойственны эксперименты в построении сюжета, системы персонажей, способе повествования. Главным в творчестве В.Б. Свена этого периода Ю.К. Терапиано находит «его неповторимо-личное ощущение человека, его моральный подход к оценке того, “чем люди живы” и ощущение рока, судьбы, незримо присутствующих всюду, с которыми почти никто из людей, особенно из людей, захваченных стихией революции, бороться не может» $[15$, c. 8].

Периоды в творчестве В.Б. Свена при этом выделяются очень условно. Этому автору свойственна именно эволюция, постепенное 
развитие и углубление черт, заложенных с самых ранних произведений и столь же медленное исчезновение других. Трем из четырех доступных в настоящий момент сборникам своих произведений В.Б. Свен дает авторское жанровое определение «рассказы». В действительности, значительная часть произведений в этих сборниках - маленькие повести или «переходные» между рассказом и повестью сочинения, жанр которых трудно определить однозначно. В один из сборников вошла даже (дав ему название) полномасштабная повесть «Уже пора».

Творческое наследие В.Б. Свена, таким образом, представляет особенный интерес и заслуживает внимания именно в своей целостности. В настоящее время в традиционном печатном виде произведения В.Б. Свена существуют, в основном, в виде малотиражных эмигрантских изданий, а также в эмигрантской периодике середины прошлого века. Хранятся такие издания в специализированных отделах библиотек и в частных коллекциях. Особо следует отметить, что кроме двух упомянутых выше недоступных сборников все издания произведений В.Б. Свена имеются в фондах Российской государственной библиотеки. В монументальную антологию В.В. Агеносова включены три рассказа писателя: «Ласточки», «Пеночка» и «Юрка» [2, с. 551-561].

Современные информационные технологии позволяют значительно ускорить процесс интеграции творческого наследия В.Б. Свена в единый отечественный литературный поток. С их помощью решается проблема доступности текстов (в отличие от доступности их печатных вариантов, которая на текущий момент крайне затруднена). В такой ситуации важной задачей становится информирование потенциального читателя (и издателя) о сути обсуждаемого литературного феномена: личности писателя и особенностях его творчества. Три книги В.Б. Свена: «Моль» [18], «Бунт на корабле» [13] и «Чей друг и чей враг Михаил Зощенко?» [19] в настоящее время оцифрованы и представлены на целом ряде сайтов. Все три работы - в «Libros», «KnigoGid» и электронном архиве «Vtoraya-literatura»; кроме сочинения о M.M. Зощенко еще в «RuLit» и «Ридли».
Думается, настало время, и появилась возможность, во-первых, опубликовать лучшие произведения В.Б. Свена в печатном виде. Вовторых, активизировать внимание к его творчеству отечественных читателей и исследователей. Совокупность таких действий позволит интегрировать творческое наследие писателя в российскую культуру, тем самым обогатив ее.

В настоящее время с основными произведениями В.Б. Свена можно ознакомиться на сайтах [20-24].

\section{Список источников}

1. Свен В.Б. Пришвинское // Грани. 1953. № 17. C. $77-87$.

2. Агеносов В.В. Свен (Кублицкий) Виктор Борисович // Восставшие из небытия : антология писателей Ди-Пи и второй эмиграции. Москва : АИРО-ХХІ, 2014. С. 548-561.

3. Свен В.Б. Цена жизни : рассказы. Мюнхен : Издание автора, 1960. $151 \mathrm{c}$.

4. Свен В.Б. Канал пяти морей: (Записки журналиста) // Грани. 1952. № 15. С. 46-57.

5. Свен В.Б. Селигер: (Очерки обыкновенных дней) // Грани. 1954. № 21. С. 60-78.

6. Свен В.Б. Охотничьи рассказы: Привычка. Дед Тит // Грани. 1953. № 17. С. 84-88.

7. Большухин Ю.Я. Обретшие слово (Сопроводительный очерк) // Литературное зарубежье : сборник-антология. Мюнхен : Центральное объединение политических эмигрантов из CССР. 1958. С. 339-354.

8. Пестрые рассказы : сборник эмигрантской прозы / под ред. В. Александрова. Нью-Йорк : Издво им. Чехова, 1953. 411 с.

9. Свен В.Б. Каламбай // Грани. 1953. № 19. С. 3435.

10. Свен В.Б. Тим // Новый журнал. 1964. № 76. C. $107-112$.

11. Свен В.Б. Волк // Новый журнал. 1964. № 76. C. $103-106$.

12. Свен В.Б. Рувим, сын Давидов : рассказы. [Германия] : Медный Всадник, 1947. 125 с.

13. Свен В.Б. Бунт на корабле. Мюнхен : Товарищество зарубежных писателей, 1961. 140 с.

14. Свен В.Б. Уже пора : рассказы. Мюнхен : Товарищество зарубежных писателей, 1966. 221 с.

15. Терапиано Ю.К. Памяти Виктора Свена // Русская мысль. Париж. 1972. 3 февр. (№ 2880). C. $8-9$. 
16. Носов Н.Н. Зарубежные публикации произведений Ю.К. Терапиано на русском языке (к 125-летию со дня рождения) // Библиотековедение. 2017. Т. 66, № 5. С. 543-552. DOI: 10.25281/0869-608X-2017-66-5-543-552.

17. Свен В.Б. Семен Осипович // Возрождение. 1967. № 189 . С. $30-50$; № 190 . С. $7-29$; № 191. C. $7-27$; № 192 . C. $7-27$.

18. Свен В.Б. Моль. Мюнхен : Товарищество зарубежных писателей, 1969. 318, [2] с.

19. Свен В.Б. Чей друг и чей враг Михаил Зощенко? Мюнхен : Центральное объединение политических эмигрантов из СССР, 1958. 64 с.

20. Свен Виктор [Электронный ресурс] // «Вторая литература» : электронный архив зарубежья имени Андрея Синявского : сайт. URL: http://www.vtoraya-literatura.com/ razdel_274_str_1.html (дата обращения: 02.04.2018).
21. Виктор Борисович Свен [Электронный ресурс] // KnigoGid : сайт. URL: https://knigogid. ru/authors/124995-viktor-borisovich-sven (дата обращения: 02.04.2018).

22. Свен Виктор Борисович [Электронный ресурс] // Libros : сайт. URL: http://www.libros. am/author/38281/sven-viktor-borisovich (дата обращения: 02.04.2018).

23. Свен В. Моль. Бунт на корабле [Электронный ресурс] // Ридли : сайт. URL: http:// readli.net/avtor/Sven-Viktor/ (дата обращения: 02.04.2018).

24. Свен Виктор : биография и книги автора [Электронный ресурс] // RuLit : сайт. URL: http:// www.rulit.me/authors/sven-viktor (дата обращения: 02.04.2018).

Иллюстрации предоставлены автором статьи

\section{Evolution of V.B. Sven's Creative Work: From Essays and Stories to the Big Epic Form}

\section{Maya E. Babicheva}

Russian State Library, 3/5, Vozdvizhenka Str., Moscow, 119019, Russia

E-mail: BabichevaME@rsl.ru

\begin{abstract}
The article for the first time attempts to introduce into the Russian cultural circulation the creative heritage of V.B. Sven, whose 120th anniversary of birth was celebrated in 2017. This writer of the second wave of Russian emigration is now almost unknown in homeland. His works, however, deserve to be noticed by Russian readers and researchers. Firstly, V.B. Sven's works, due to their high artistic level, are an integral part of Russian culture. Secondly, the writer reflected in his literature a number of interesting historical and cultural phenomena, characteristic of the era he wrote about. A literary analysis of V.B. Sven's works is given in correlation with his unusual biography. Many facts from the writer's life are reflected only in sources difficult to access;
\end{abstract}

they are presented to a wide audience in this work for the first time.

The article considers the specifics of V.B. Sven's creative style in the evolutionary development. The article develops a periodization of the literary array created by the writer and justifies the conditionality of its division into periods. It shows the influence of M.M. Prishvin on the work of V.B. Sven, determines the place of the writer in the emigrant literature, analyzes the reviews of his works written by his contemporary critics-emigrants. Much attention is paid to the artistic innovation of V.B. Sven, his experiments in the field of artistic form, inherent in later works. The article highlights the mystical element in the worldview and, accordingly, in works of the writer, and the specific cultural phenomenon closely associated with it Miklashevsky's "system", which became the content and structural center of one of his works.

The article distinguishes between the difficulty of seeing any V.B. Sven's lifetime printed publications, on the one hand, and the availability of texts of his works in digitized form, on the other. There is emphasized the importance, in a situation like this, of information about the existence of the works, about their merits and accessibility. The references to the article include a list of sites where the main works of the author can be found. 
Key words: V.B. Sven, Russian emigration, social conflict, revolution, evolution, culture, literature, creative heritage, genre, psychologism.

Citation: Babicheva M.E. Evolution of V.B. Sven's Creative Work: From Essays and Stories to the Big Epic Form, Observatory of Culture, 2018, vol. 15, no. 3, pp. 330-339 DOI: 10.25281/2072-31562018-15-3-330-339.

\section{References}

1. Sven V.B. Prishvin's, Grani [Facets], 1953, no. 17, pp. 77-87 (in Russ.).

2. Agenosov V.V. Sven (Kublitsky) Viktor Borisovich, Vosstavshie iz nebytiya: antologiya pisatelei $\mathrm{Di}-\mathrm{Pi} \mathrm{i}$ vtoroi emigratsii [Risen from the Oblivion: An Anthology of the Writers of Displaced Persons and of the Second Emigration]. Moscow, AIRO-XXI Publ., 2014, pp. 548-561 (in Russ.).

3. Sven V.B. Tsena zhizni: rasskazy [The Price of Life: Stories]. Munich, Author's Publ., 1960, 151 p.

4. Sven V.B. The Channel of Five Seas: (Journalist's Notes), Grani [Facets], 1952, no. 15, pp. 46-57 (in Russ.).

5. Sven V.B. Seliger: (Essays of Ordinary Days), Grani [Facets], 1954, no. 21, pp. 60-78 (in Russ.).

6. Sven V.B. Hunting Stories: The Habit. Grandpa Tit, Grani [Facets], 1953, no. 17, pp. 84-88 (in Russ.).

7. Bolshukhin Yu.Ya. Those Who Found the Word (An Accompanying Essay), Literaturnoe zarubezh'e: sbornik-antologiya [Literary Emigration: CollectionAnthology]. Munich, Tsentral'noe Ob"edinenie Politicheskikh Emigrantov iz SSSR Publ., 1958, pp. 339-354 (in Russ.).

8. Aleksandrov V. (ed.) Pestrye rasskazy: sbornik emigrantskoi prozy [The Motley Tales: Collected Emigrant Prose]. New York, Imeni Chekhova Publ., 1953, $411 \mathrm{p}$.

9. Sven V.B. Kalambay, Grani [Facets], 1953, no. 19, pp. 34-35 (in Russ.).

10. Sven V.B. Tim, Novyi zhurnal [New Journal], 1964, no. 76, pp. 107-112 (in Russ.).

11. Sven V.B. A Wolf, Novyi zhurnal [New Journal], 1964, no. 76, pp. 103-106 (in Russ.).

12. Sven V.B. Ruvim, syn Davidov: rasskazy [Ruvim, Son of David: Stories], Mednyi Vsadnik Publ., 1947, 125 p.
13. Sven V.B. Bunt na korable [Mutiny on the Ship]. Munich, Tovarishchestvo Zarubezhnykh Pisatelei Publ., 1961, 140 p.

14. Sven V.B. Uzhe pora: rasskazy [It's Time: Stories]. Munich, Tovarishchestvo Zarubezhnykh Pisatelei Publ., 1966, $221 \mathrm{p}$.

15. Terapiano Yu.K. To the Memory of Viktor Sven, Russkaya mysl' [Russian Thought]. Paris, 1972, February 3 (no. 2880), pp. 8-9 (in Russ.).

16. Nosov N.N. The Foreign Publications in Russian of the Works of Yu.K. Terapiano (To the 125th Birth Anniversary), Bibliotekovedenie [Library and Information Science (Russia)], 2017, vol. 66, no. 5, pp. 543-552 (in Russ.). DOI: 10.25281/0869608X-2017-66-5-543-552.

17. Sven V.B. Semyon Osipovich, Vozrozhdenie [Renaissance], 1967, no. 189, pp. 30-50; no. 190, pp. $7-29$; no. 191 , pp. $7-27$; no. 192 , pp. $7-27$ (in Russ.).

18. Sven V.B. Mol' [A Moth]. Munich, Tovarishchestvo Zarubezhnykh Pisatelei Publ., 1969, 318 p.

19. Sven V.B. Chei drug i chei vrag Mikhail Zoshchen$k o$ ? [Whose Friend and Whose Enemy Is Mikhail Zoshchenko?]. Munich, Tsentral'noe Ob"edinenie Politicheskikh Emigrantov iz SSSR Publ., 1958, $64 \mathrm{p}$.

20. Sven Viktor, "Vtoraya literatura": elektronnyi arkhiv zarubezh'ya imeni Andreya Sinyavskogo: sait ["The Second Literature”: Andrei Sinyavsky Electronic Archive of Emigration: website]. Available at: http:// www.vtoraya-literatura.com/razdel_274_str_1. html (accessed 02.04.2018) (in Russ.).

21. Viktor Borisovich Sven, KnigoGid: website. Available at: https://knigogid.ru/authors/124995viktor-borisovich-sven (accessed 02.04.2018) (in Russ.).

22. Sven Viktor Borisovich, Libros: website. Available at: http://www.libros.am/author/38281/sven-viktorborisovich (accessed 02.04.2018) (in Russ.).

23. Sven V. A Moth. Mutiny on the Ship, Ridli: website. Available at: http://readli.net/avtor/Sven-Viktor/ (accessed 02.04.2018) (in Russ.).

24. Sven Viktor: The Author's Biography and Books, RuLit: website. Available at: http://www.rulit. me/authors/sven-viktor (accessed 02.04.2018) (in Russ.). 